\title{
Supplier development practices for sustainability: a multi-stakeholder perspective
}

\begin{abstract}
:
Supplier development for sustainability is a critical element of sustainable supply chain management and requires extensive multi-stakeholder collaboration. This article establishes a conceptual four-stage framework to analyse the collaborative mechanisms of supplier development practices, and presents an exploratory, qualitative analysis to identify the major contributors of sustainable supplier development practices, such as NGOs, industrial associations, consulting firms, etc. Based on semi-structured interviews towards 63 organisations from different regions and industries, this article identifies three types of contributors: Drivers, Facilitators and Inspectors. Instead of traditional stakeholder engagement processes, these contributors actively collaborate with buying firms and suppliers to design, implement and evaluate sustainable supplier development programs. The article then provides a matrix to describe the supply chain coverage and supplier performance of supplier development practices, given the absence or positive involvement of Facilitators and Inspectors. We conclude our study by suggesting future research directions as well as discussing managerial implications.
\end{abstract}

Keywords:

Sustainable development, supply chain management, sustainable collaboration, capacity building, stakeholder engagement, environmental NGOs 


\section{Introduction}

Nowadays, the global competitiveness of businesses is not only about the firms themselves, but also about their supply chains ( $\mathrm{Li}$ et al. 2006). Therefore, in the face of sustainable development challenges, sustainable supply chain management (SSCM) has become a key strategy for many global businesses (Seuring and Müller 2008), not only because of their commitments and agendas on sustainability, but also because such strategies can be beneficial in terms of commercial performance, product innovation (Lee and Kim 2011), or risk management (Hofmann et al. 2014).

Among common SSCM actions, supplier development is considered as a core strategy. Traditional supplier development can be defined (Krause et al. 2000) as "any activity undertaken by buying firms to improve supplier performance and/or supplier capabilities, in order to meet the buying firms' short- and/or long-term supply needs." Given current sustainability challenges, buying firms (BFs) need to consider several facets of supplier performance when undertaking supplier development activities, including economic performance, environmental performance, and ethics-related social performance.

Since the sustainability goals of BFs can be newly emerged, developed or evolved, and the transactional cost of supplier replacement can be high in many industrial sectors, supplier development becomes increasingly important if BFs wish to improve the social and/or environmental performance of a certain supplier cohort, whose economic performance and supplying capacity are either satisfactory or too valuable to be replaced. Thus, supplier development for sustainability (SDS) is not only emerging as a main approach of managing supply chain sustainability issues (Yawar and Seuring 2015), but also interrelated with other actions such as supplier selection or evaluation (Zimmer et al. 2016).

Although most of the sustainability or responsibility reports of global brands will mention their SDS practices, the literature on SDS is not rich. Prior studies generally focus on green 
supplier development practices. Such studies use a single company case study design, and address the environmental performance of suppliers (Bai and Sarkis 2010, Fu et al. 2012, Dou et al. 2014, Dou et al. 2015), which is reasonable because single-company data is already challenging to acquire, and the social issues of suppliers, such as labour, safety or occupational hazards, are more complicated than environmental issues. Prior studies also consider stakeholders as external or contextual (Busse 2016) of supply chain management and SDS practices, e.g., the drivers (Sancha et al. 2015) that influence BFs and them alone. Such studies have established dyadic frameworks (Distelhorst et al. 2015, Busse et al. 2016) or multi-tier networks (Mena et al. 2013, Tachizawa and Wong 2014), which they have used to analyse buyer-supplier interaction in SDS. However, their findings may no longer be accurate in the continuously evolving reality, since there is also evidence of active stakeholder involvement from neither buyers nor suppliers, which directly and significantly contributes to supply chain management and SDS practice. Two examples of influential SSCM initiatives managed by such contributors are:, firstly, the 'Carbon Disclosure Project' which has provided the $\mathrm{CO}_{2}$ emission criteria for companies like BMW to conduct supplier engagement and development ${ }^{1}$; and secondly the 'International Cocoa Initiative' which, working with a number of leading food businesses ${ }^{2}$, regularly trains different cocoa suppliers and farmers on child labour issues in the cocoa sector. Despite the richness of business practices and stakeholder participation, there are no theoretical models that explain the formation of SDS practices, and there is very limited research about the evaluation and selection of SDS practices (Zimmer et al. 2016). As a result, the current studies cannot reflect the real-world problems of SDS, where BFs and suppliers are no longer the only two players. The current studies are also not sufficient to enlighten business decision makers to design and

\footnotetext{
${ }^{1}$ https://www.cdp.net/en/articles/governments/case-study-bmw-groups-strategic-supplier-engagement

${ }^{2}$ http://www.cocoainitiative.org/about-ici/our-partners/industry-members/
} 
develop their own SDS practices, or to help them understand the pros and cons of their current practices.

Therefore, the purpose of this paper is to answer two research questions: 1) Besides BFs and suppliers, what are the participatory roles of primary contributors during SDS practices? 2) How are those roles shaping the goals, processes, and effectiveness of SDS practices?

The remainder of the article is structured as follows. We begin by reviewing relevant concepts in the SDS literature and direct our attention to how SDS in the real world has evolved so far. Subsequently, we describe our qualitative approach based on semi-structured interviews and exploratory studies. We then answer our research questions based on an open coding process. The most important academic contribution of our paper is to apply a multistakeholder perspective to the previous analytical frameworks of buyer-supplier relationships, and establish a conceptual model for the formation and implementation of SDS practices. As to practical contributions, the article might be useful for adaptive management and codesigning SDS practices among BFs, suppliers and key stakeholders. We conclude the paper with theoretical and managerial insights, as well as the limitations of our studies and suggestions for future research.

\section{Supplier development for sustainability: conceptualization of the real-world problems} There are a few insightful concepts and models in place for traditional supplier development practices (Hahn et al. 1990). When it comes to sustainability, most of the empirical studies or theoretical developments (Bai and Sarkis 2010, Lu et al. 2012, Busse et al. 2016) are still based on a framework of strategies proposed by Krause (Krause et al. 2000): Competitive pressure (CP), Incentives (IC), Evaluation \& Assessment (EA), and Management involvement (MI). More recently, a fifth element has been integrated into the framework: knowledge transfer (KT) (Modi and Mabert 2007, Dou et al. 2015). 
However, researchers have not yet developed this framework in the context of sustainability (Table 1). Yet research shows that, due to the complex nature of sustainability challenges and the consequent fast evolution of business agendas (Meckenstock et al. 2015), the BFs have to develop specific capacities for implementing their SDS strategies (Rueda-Manzanares et al. 2008), but they may not have sufficient knowledge or resources to do so alone - especially when their businesses have wide coverage and high diversity, in terms of industrial sectors (e.g., food, grocery and retailing) and geographical regions. Meanwhile, the selected suppliers of SDS practices are also in desperate need to be competitive, cooperative and adaptive, and the help they need does not always come from their BFs. In some cases, BFs offer minimum support, thus the supplier development activities are merged with the natural business processes of supplier selection and evaluation (Wagner 2011). Therefore increasingly, both BFs and suppliers are seeking external help (Fu et al. 2012, Dou et al. 2015, Sancha et al. 2015, Vermeulen 2015) to acquire the necessary knowledge and resources. Thus, we believe that there are important roles for actors other than BFs and suppliers, during SDS practices, not only to provide coercive, normative and mimetic drivers (Zhu et al. 2013, Sancha et al. 2015), but also as direct contributors in different stages of SDS practices.

In order to explore the different contributors and their specific roles in the formation of SDS practices, first we present a simple conceptual model that includes a four-stage SDS cycle (Figure 1), which includes: Designing; Recruiting \& engagement; Implementing \& monitoring; as well as Conclusion \& reflections. All stages are managed by BFs and targeted at suppliers, but as mentioned in the previous paragraph, we assume that each stage also involves the participation of additional contributors, and this assumption will be investigated during our research. The five strategies of traditional supplier development, namely Competitive pressure (CP), Incentives (IC), Evaluation \& Assessment (EA), Management 
involvement (MI) and Knowledge Transfer (KT), have also been integrated into the fourstage model in Figure 1, in order to conceptualize how and when BFs choose to implement these strategies. In the real world, one SDS cycle in Figure 1 can vary in length from a few months to a few years. The completion of one SDS cycle can lead to various results, including supplier selection (or re-selection), continuous improvement of supply chain management performance metrics, or the termination of a specific SDS project.

We now proceed to research design and data collection based on our conceptual model.

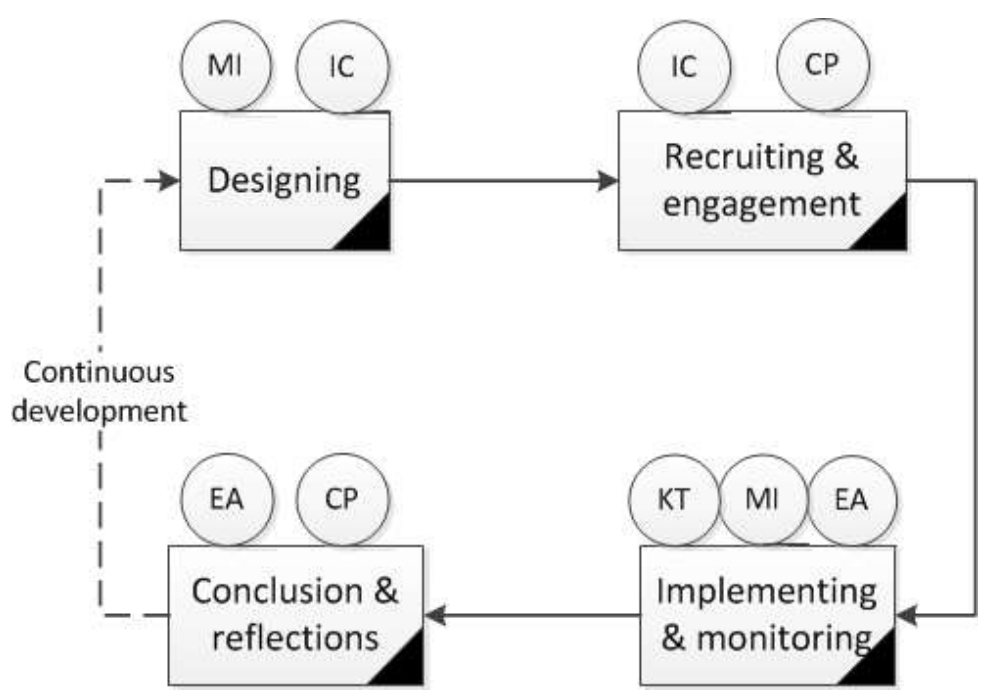

Figure 1 Conceptual cycle of supplier development practices for sustainability Adapted from models and concepts of (Hahn et al. 1990, Giannakis 2008, Dou et al. 2015)

\section{Research method}

Given the incomplete development of theories in sustainable supply chain management (Pagell and Wu 2009, Tachizawa and Wong 2014) and the explorative nature of the research topic, a multi-case study approach was applied to enable in-depth investigation (Eisenhardt 1989, Yin 2002, Voss et al. 2016) towards organisations and their SDS practices. 


\section{Sampling}

Our qualitative multi-case research draws on face-to-face semi-structured interviews towards 63 organisations in order to analyse the overall SDS practices that they have managed or in which they have been involved. Interviewed organisations include: supplier companies, multi-national companies as BFs, and the other contributors to SDS practices (Table 2). We applied a three-stage, snowball sampling method to select the organisations. Firstly, we selected the BFs using three criteria: 1) organisations which regularly publish sustainability reports about their supply chains, 2) organisations actively investing in supplier development activities and 3) active members of leading global environmental NGOs, e.g., World Wildlife Fund (WWF), The Sustainability Consortium (TSC) or World Business Council of Sustainable Development (WBCSD), etc. We then sent out invitations to those BFs of participating or co-organizing workshops in China. Nine of the invited BFs agreed to participate, and we naturally asked the BFs to identify their Chinese suppliers, who have been working with them for at least three years and have jointed SDS efforts. A total of 41 suppliers agreed to participate.

In the selection process we ensured all BFs are multi-national, and we have made best efforts to cover BFs and suppliers from different industrial sectors. To manage the research within a limited budget and resources, while ensuring the coverage of different industrial sectors, we chose to host interviews and workshops in east and south China, so that at the export or supplier end (Wei and Liu 2006), it is our best chance to cover as many industrial sectors as possible. We then hosted 10 different knowledge sharing and capacity building workshops with SDS themes or purposes, during which we conducted face-to-face interviews. Finally, based on the information provided by BF and/or supplier organisations, as well as secondary sources from press clippings, newsletters, and corporate sustainability reports of selected BFs, we interviewed 13 contributors of SDS practices, including researchers and external experts, 
consultancy and training agencies, industrial associations and NGOs. The demographic information of the organizations are presented in Table 2.

\section{Insert Table 2 here}

\section{Data collection}

Semi-structured interview protocols were used to collect data. All interview questions targeted the overall SDS practices in which the interviewees have participated, and therefore the research was not limited to SDS projects that simultaneously involved the interviewed BFs, suppliers and contributors. The interview questions were developed based on the existing literature and the research framework, and are shown in Appendix 1. The interviewees have a diverse background based on the nature of their employers, and those who have a global background were asked about SDS in a global context. All interviewed suppliers are based in China. The sampling criteria for individual interviewees were also established to ensure that we collected unbiased and diverse opinions from experienced individuals. The supplier interviewees have work experience between three years to 15 years, and at least three years in sustainability-related management. All other interviewees have at least five years of work experience that directly involved at least two SDS projects, initiated by either different BFs or different sustainability initiatives. The records from different individual participants of the same organisation were cross-checked (e.g., an environment manager and a safety manager from the same supplier facility). The interviews were conducted between April 2014 and Feb 2015, and each of the interviews ranged in length from 45 to 90 minutes. 42 interviews were audio recorded, with consent on condition of anonymity, and transcribed verbatim to ensure accuracy. The rest of the interviews were recorded by typing on laptops real-time during the conversations due to the confidentiality requirement of interviewees. Interviews conducted in Mandarin were translated by the lead author who is fluent in the language. 
We also used multiple sources of information to help design the interview questions and to triangulate the data collected. The sources included the publicly available reports regarding sustainability or corporate social responsibility (CSR) of BFs, as well as the websites and annual impact reports of NGOs. The triangulation mainly included: 1) understanding the context of specific SDS activities prior to the interviews, thus enabling us to prepare the conversational questions in an efficient way; 2) the confirmation or verification of mentioned contributors and their contribution in a given SDS practice; 3) the effectiveness of a given SDS practice in the form of supply chain coverage or supplier performance improvement, mentioned in an interview.

\section{Analysis and results}

The unit of analysis is the individual organisations - i.e., BFs, suppliers and contributors and their overall contribution to SDS practices. Data analysis was carried out by coding the data, using both open coding and constructs from the sustainability management literature and the supplier development literature. We then applied an explanation building strategy (Yin 2009) to propose the key roles of contributors that were identified among those activities. In order to do that, we repeated the following processes: 1) Identify descriptive actions of BFs and suppliers (Table 3) in different stages of SDS practices. 2) Propose in theory the different mechanisms and strategies that actively involve the contributors other than BFs and suppliers. 3) Analyse the quotes and use coding to categorize the contributors and their approaches to make impacts. 4) Refine the proposed mechanisms and strategies. The remainder of this section will report the findings. 


\section{Drivers, Facilitators and Inspectors}

Based on the open coding analysis of the interview records, our research shows that, besides BFs and suppliers, there are definitely more contributors that are directly involved in all four stages of SDS practices. Working closely with BFs and suppliers, they play important roles of shaping the formation, process and effectiveness of SDS practices. We hereby define those roles as: Drivers, Facilitators, and Inspectors (Table 4).

\section{Insert Table 4 here}

Drivers are the organizations that provide pressure and/or incentives to initiate SDS practices. Drivers also shape and co-design the preliminary objectives and directions of such practices, together with BFs. Typically they have access to the decision makers of BFs, and they are mission-driven about specific supply regions or sustainability issues. We consider them as direct contributors instead of external stakeholders (Rueda-Manzanares et al. 2008, Wu 2015), because they not only create pressure (Foerstl et al. 2015) for firms to take actions on supply chain sustainability, but also help BFs to determine which sustainability-related issues (e.g., carbon, water, child labour, etc.) are more crucial, more relevant, and can be improved through SDS practices, thus in some cases, "the program won't even exist if not for them (the Driver NGO) - I'd just go back to the office and write those boring CSR reports then". The Driver role is significantly active at the Designing stage.

Facilitators are the organizations that provide knowledge and/or resources for SDS practices, in order to either make the engagement and implementation more efficient and localized, or scale up the impact of practices. Many such efforts are conducted through bridging efforts (Rodríguez et al. 2016) and training (Touboulic et al. 2014). For example, by “creating a precompetitive alignment", Facilitators can "engage with several BFs and deliver SDS programs to their mutual suppliers" to mitigate supplier frustration; by offering financial or technical 
support, Facilitators can also help the diffusion of sustainability practices from the best suppliers to other suppliers. Facilitators are particularly active in the stage of Recruiting \& engagement and Implementation \& Monitoring. In the case of supplier capacity building and knowledge transfer, the Facilitators can also act as a co-organizer, moderator, or coordinator. Inspectors provide a neutral and scientific ground for SDS practices. During the stages of Implementation \& Monitoring and Conclusion \& Reflections, their role is to advise and plan for SDS goals and benchmarks, to provide technical expertise to ensure the quality of supplier development, and to validate the performance of suppliers. Unlike Drivers or Facilitators, Inspectors in many cases have a weak link with BFs and suppliers (if any at all) in order to maintain neutrality and avoid conflict of interests. Due to the business confidentiality of many supplier development activities, a major part of the data collection during such monitoring, auditing or evaluation might even be conducted by the staff of BFs themselves (Doorey 2011, Marshall et al. 2016), but it does not change the existence of Inspectors, since in those cases they still contribute to the designing of indicators and the methodology of evaluation.

Therefore, we bring forward the first proposition regarding sustainable supplier development:

\section{Proposition 1}

Supplier development for sustainability requires the active involvement of contributors other than buyers and suppliers, and those contributors can be categorized as a Driver, a Facilitator or an Inspector.

Among the three contributors, Facilitators and Inspectors are relatively new roles in supplier development, but cannot be simply categorized as external stakeholders, or outsourcing 
contractors of supplier development programs. We think their emergence are inevitable due to the wicked nature of sustainability challenges (Meckenstock et al. 2015). Firms are no longer envisioning the scope and interpretation of supply chain sustainability on their own, while the participation of business associations, sustainability initiatives and technical consultants/experts have offered additional incentives, knowledge or resources. It is then intriguing for us to notice that in our research, the roles of Drivers are mentioned in almost every interview we've conducted, while the Facilitators and Inspectors are not always mentioned by interviewees from BFs or suppliers. As a result, we continue our analysis to explain what happens to SDS practices if those two roles are either absent or not effective enough.

\section{Coverage and performance of SDS practices}

To clearly understand the influences of Facilitators and Inspectors in SDS practices, we looked into the interview records that described the feedback and experience about the outcomes of SDS practices. If the outcomes have been evaluated at least once, the interviewees were asked about those outcomes in a descriptive way, so that the sensitivity to business confidentiality can be minimized. Those descriptions are then cross-checked through official supplier development reports or supplier responsibility reports that are available to the public.

We found that there are two approaches to describe and evaluate (or at least self-evaluate) the outcomes of SDS practices: coverage, and performance. The coverage approach pays attention to the workload and resources that have been invested and emphasises their achievement with high coverage of the supplier community. The program is moderated by the degree of human interaction (Wagner and Krause 2009), and evaluation if any, is either qualitative or statistical. Our interviewees describe the coverage approach with narratives 
such as: "Our compliance program has covered X (numbers) facilities of our suppliers";

“We offer training courses to Y (numbers) sustainability managers of our suppliers and 90\% of them have found the course highly interesting and satisfactory"; or "Our responsible supplier initiative covers all of the countries and regions that our suppliers are based in." etc.

In contrast, the performance approach pays attention to the behavioural and managerial results of suppliers in the aspect of environmental or social sustainability, both before and after the implementation of SDS practices, and the evaluation is both quantitative and analytical (Bai and Sarkis 2014). Our interviewees described the performance approach with narratives such as: "The average recycling rate of participating supplier factories was $55 \%$ last year, and rose to $90 \%$ this year, certified by [name of organisation].”; Occupational injuries per thousand workers have dropped from 5 a year to zero."; or "70\% of participating supplier factories now report their annual greenhouse gas emission inventory, and their energy efficiency has an annual improvement of 10\%."etc.

\section{Insert Table 5 here}

To further understand those two dimensions for describing SDS practices, we compared the instances in the interview records for "coverage" versus "performance" with the interviewees' comments regarding the roles of Facilitator and Inspector. Our major findings are presented in Table 5 and Figure 2 through a matrix of sustainable supplier development. The plus (+) sign in Table 5 and Figure 2 implies that the interviewees recognize this role as "actively involved", and probably have been interacting with this role at an organizational level for a certain SDS project. The minus (-) sign implies that the interviewees did not mention this role, or suggested that this role is either absent or not active when talking about an SDS project. 


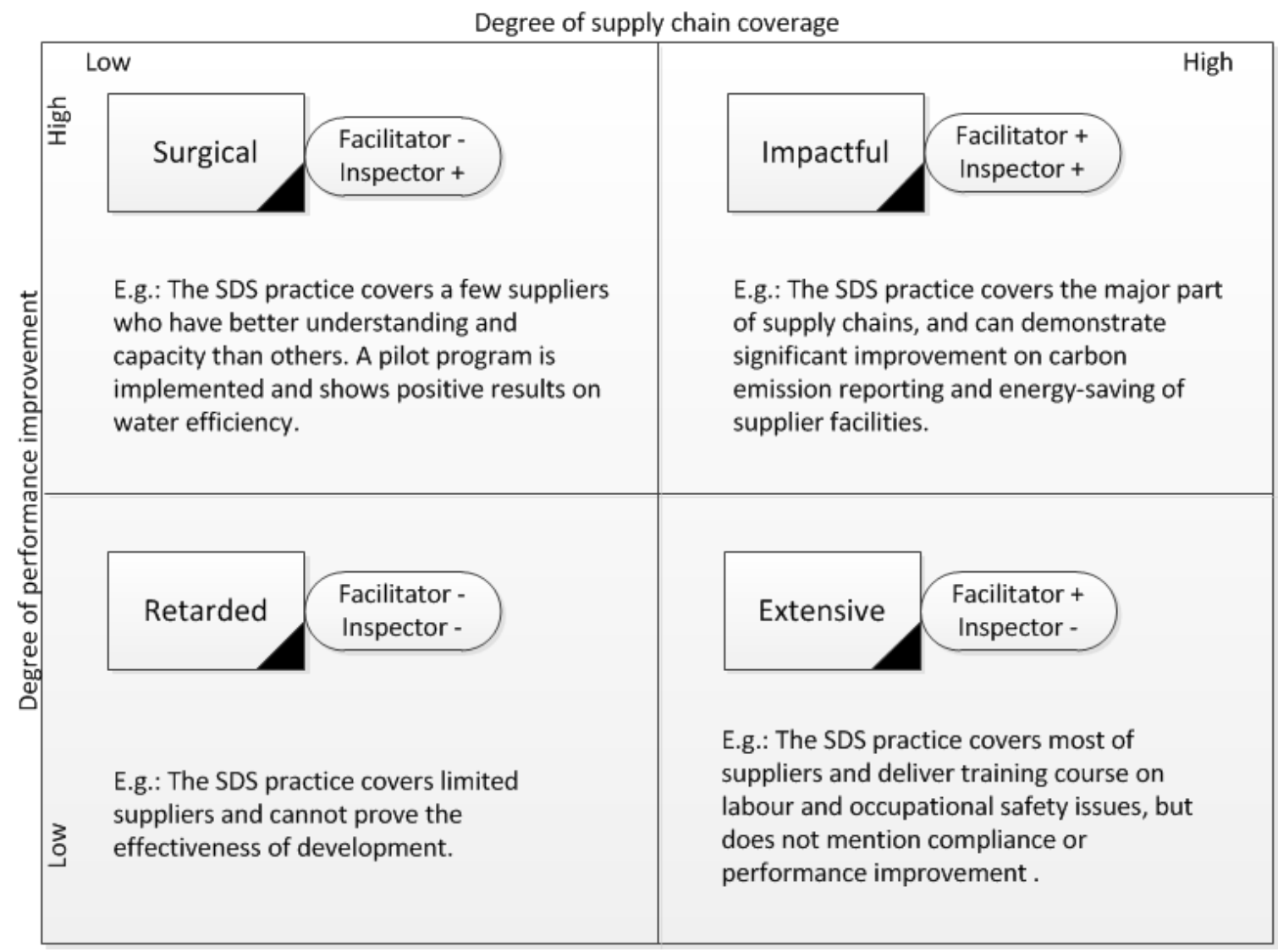

Figure 2 The matrix of sustainable supplier development: efforts and performance

Our findings suggest that the BFs and Drivers will always prefer to pursue the ideal SDS practices (impactful), which should include both wide-coverage of suppliers and excellent, accountable performance improvement. However, this ideal is not always realistic given that such impacts require much internal and external resources, while the Drivers - especially the campaigning NGOs, might not be able to provide those resources. In the cases that BFs have limited resources and are not aggressive in sustainable supply chain management, they usually decide to take minimum actions (retarded) so that "they can show us that at least they are making some effort", quoting a membership manager in an environmental NGO. As a result, during the Designing stage, BFs that are restrained by resources may try to find a middle ground (either extensive or surgical) for the expected outcomes of SDS practices, based on the limited resources at hand. We believe that the involvement of Facilitators or Inspectors helps to achieve such middle ground: the SDS practices with an effective 
Facilitator are more likely to end up with good coverage (extensive), while those with an effective Inspector are more likely to end up with good performance (surgical).

Therefore, we bring forward the second proposition regarding sustainable supplier development:

\section{Proposition 2}

Supplier development practices for sustainability shall be evaluated using two dimensions: supply chain coverage and supplier performance improvement.

\section{Proposition 2a}

Facilitators can help improve the supply chain coverage of SDS practices by providing resources of knowledge, expertise and networking.

\section{Proposition 2b}

Inspectors can help improve supplier performance improvement of SDS practices by providing neutrality, accountability and transparency.

Meanwhile, our findings do not provide clear evidence regarding the way Drivers influence the implementation of SDS practices. Drivers are significantly active in the Designing stage, and usually play a crucial role to lobby BFs to pay more attention to sustainability challenges along their supply chains. But there is no strong evidence in our study suggesting whether and how Drivers would contribute to better coverage or sustainability performance of supply chains. Since only three organisations were identified as Drivers in our study, we think the role of Drivers in the coverage-performance analytical framework is so far unclear and requires further research. We did identify, however, two specific NGOs, one of which is considered to be both a Driver and a Facilitator (N2), and the other is considered to be both a 
Driver and an Inspector (N3). Thus in the section below we will further discuss these two examples specifically in order to revisit the SDS cycle using a dynamic view.

\section{SDS practices in a dynamic view}

Through this study we found that our conceptual model in Figure 1could be integrated with the three roles that we have identified, but more importantly, the presence and contributions of the three roles can be dynamic (Figure 3). There are rarely any perfectly-designed SDS practices in which every single role and participator are in place since the very beginning. In most cases, organisations are learning by doing. Such organisational learning (Smith 2012) happens to BFs and suppliers who might allocate resources to identify and invite new Facilitators and Inspectors to join a specific cycle of SDS practice. It can also happen to contributors, who might adopt different strategies or even shift to a different role, in order to help BFs achieve the goals of sustainable supply chain management.

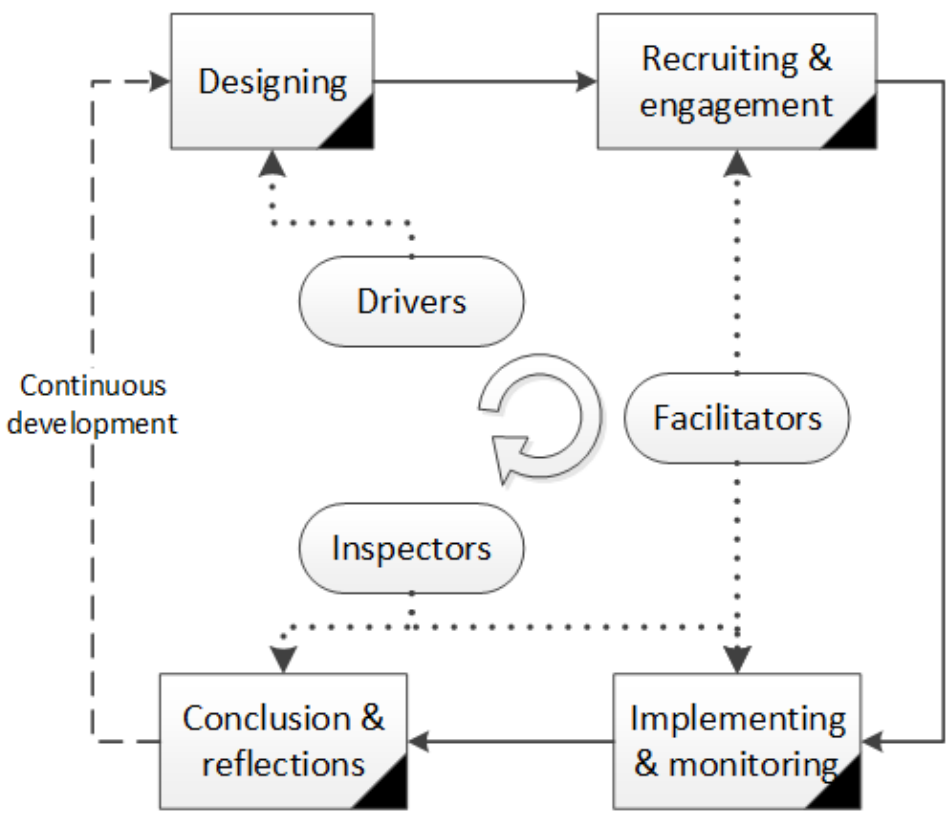

Figure 3 The cycles and contributor roles of supplier development practices for sustainability 
While Oelze et al. (2016) suggested that collaborating with NGOs is a crucial process for the organisational learning of western companies regarding supply chain management (Oelze et al. 2016), our result shows that NGOs can also learn and adapt their roles in order to better collaborate with BFs during such processes to solve the challenges during supplier development. In the NGO examples that we have identified, there are at least two potential explanations:

1) Must-do: the SDS practice itself is so novel and outstanding that other external stakeholders or professional services are not mature enough to provide sufficient help Quotes from N2:

“...After we decided that we are going to help [name of BFs] train their suppliers about sustainability reporting along the supply chains, we tried to identify training partners since we've never done that before, not to mention in China. But we couldn't find anyone - even if there are any potential consultants, we'll still have to train the trainers first. ...So eventually we managed to get some seed funding to build a local team within our own organisation."

2) Can-do: the established vision, reputation of the NGO, and the trust between it and the $\mathrm{BF}(\mathrm{s})$ allows roles to change:

Quotes from N3:

"During the program design stage we had several discussions with [name of BF] about the ownership of the program. As you know, they (the BF) can be very concerned about confidentiality, so at last it became "their program". But it was our idea, you know... So our board was like, "we need to know what's going on, and how effective it is." Because the lesson could be invaluable to other projects of ours. And because we have this history, they recognise us as a trusted partner. So when we made the offer to evaluate the program, they agreed." 
Therefore, we bring forward the third proposition regarding sustainable supplier development:

\section{Proposition 3}

Supplier development for sustainability has a dynamic nature. In one or multiple SDS cycles, the emergence or the changing roles of contributors can be achieved through strategic collaboration, adaptive management or organisational learning of both BFs and NGOs.

\section{Discussion and Conclusion}

Sustainable supplier development practices have a life cycle that involves multi-stakeholder contributions. In this article we argued that SDS practices may be designed, influenced, and implemented with, or even by contributors who take on the roles of Drivers, Facilitators and Inspectors. From a supplier development perspective, our research verified the observations that stakeholders can be regarded as active participants of sustainable supply chain management (Pagell and Wu 2009) and risk management (Busse et al. 2017). Depending on the engagement with these roles and the resources from buying firms and suppliers, SDS practices can be impactful, surgical, extensive, or retarded. The research also lead to managerial insights for the practitioners of SDS projects indicating that: firstly it is crucial to identify proper Facilitators and Inspectors for the projects from the designing stage; and secondly that the effectiveness of SDS practices can be evaluated using two dimensions: the level of coverage of supply chains or networks, and the traceable, verifiable performance improvement of each supplier.

Although we have conducted our study with vast numbers of in-depth interviews which covered different stakeholders, our research is limited to the study of SDS practices for which the ownership lies with the BFs, while other contributors are inherently responsive or participatory. This is due to the sampling process which started with invited BFs rather than a comprehensive list of numerous SDS projects, as we did not have access to the latter. Thus 
our research could not look closer at each program to further examine the collaboration between BFs, suppliers and contributors, and the mechanisms behind such collaboration that might determine the shaping of the three roles of Driver, Facilitator and Inspector. Thus there are a number of outstanding research questions that could be addressed in future research, including the following: Is it possible for NGOs and industrial associations to be both a Facilitator and an Inspector? Is it possible that the roles were decided and/or redefined when different NGOs are working together? What are the decision-making and organisational learning processes of shifting roles? And lastly, beyond sustainable supplier development, will those versatile or adaptive organisations be more or less efficient/effective in sustainability collaboration (Govindan et al. 2016, Niesten et al. 2017)? The next stage of proposed research should look into the organizational structures of both suppliers, business associations and membership-based NGOs, and find out whether and how the characteristics of organizational structures and inter-organizational collaborations will influence the effectiveness of sustainable supply chain management.

Supplier development practices usually involve different organizations that cross diverse regions, countries and cultures. Regretfully, our analysis has not yet been able to cover the roles of local authorities and regulations in supplier development, especially given the supplier sampling region - China is known for strong policy \& regulations versus poor enforcement of both environmental and social sustainability issues (Liu et al. 2010). Preliminary results from our interviewees have shown that many BFs do require suppliers to meet the environmental and social regulatory standards of local governments, and thus intentionally design and implement SDS programs to promote suppliers' understanding on those regulatory standards. However, further research is required to analyse whether SDS practices have a spill-over effect on improving the enforcement of sustainability-related regulations. Moreover, an important research question would be whether and how BFs will 
refer to standards in the public sector to guide their own standards and practices in sustainable supply chain management (Fiorino and Bhan 2014, Vermeulen 2015). Neither has our analysis covered the media and consumer perspective of SDS practices. Sustainable supplier development is apparently part of the BFs' sustainability strategies, which are usually disclosed to the media and consumers in the format of websites, videos, social media and reports (Morhardt 2010). We thus call for further research to analyse how BFs, Drivers and Facilitators may use such instruments to ensure, exaggerate, or even twist the impacts of their SDS practices.

It is also interesting to note that our study contrasts with that of Busse et al. (2016) as we did not identify significant contextual barriers for SDS (Busse et al. 2016), even though both studies included Chinese suppliers. Thus we assume that the effective participation of Facilitators can help to bypass the contextual barriers by providing local context and priorities for sustainability issues, but this assumption requires more empirical studies that cover more developing or underdeveloped countries, where BFs are not as localized as they are in China, and where the socioeconomic context may lead to different priorities in sustainable supply chain management. Thus future research could consider other regions, such as in Africa and Latin America, where NGOs and sustainability initiatives can play a more significant role than that in our studies, so that our framework of Drivers, Facilitators and Inspectors might be further evolved and developed.

\section{References}

Bai, C. and J. Sarkis (2010). "Green supplier development: analytical evaluation using rough set theory." Journal of Cleaner Production 18(12): 1200-1210.

Bai, C. G. and J. Sarkis (2014). "Determining and applying sustainable supplier key performance indicators." Supply Chain Management-an International Journal 19(3): 275-291.

Busse, C. (2016). "Doing Well by Doing Good? The Self-interest ofBuying Firms and Sustainable Supply ChainManagement." Journal of Supply Chain Management 52(2): 28-47. Busse, C., M. C. Schleper, M. L. Niu and S. M. Wagner (2016). "Supplier development for sustainability: contextual barriers in global supply chains." International Journal of Physical Distribution \& Logistics Management 46(5): 442-468. 
Busse, C., M. C. Schleper, J. Weilenmann and S. M. Wagner (2017). "Extending the supply chain visibility boundary: Utilizing stakeholders for identifying supply chain sustainability risks." International Journal of Physical Distribution \& Logistics Management 47(1): 18-40.

Distelhorst, G., R. M. Locke, T. Pal and H. Samel (2015). "Production goes global, compliance stays local: Private regulation in the global electronics industry." Regulation \& Governance 9(3): 224-242. Doorey, D. J. (2011). "The Transparent Supply Chain: from Resistance to Implementation at Nike and Levi-Strauss." Journal of Business Ethics 103(4): 587-603.

Dou, Y., Q. Zhu and J. Sarkis (2014). "Evaluating green supplier development programs with a greyanalytical network process-based methodology." European Journal of Operational Research 233(2): 420-431.

Dou, Y., Q. Zhu and J. Sarkis (2015). "Integrating Strategic Carbon Management into Formal Evaluation of Environmental Supplier Development Programs." Business Strategy and the Environment 24(8): 873-891.

Eisenhardt, K. M. (1989). "Building Theories from Case Study Research." The Academy of Management Review 14(4): 532-550.

Fiorino, D. J. and M. Bhan (2014). "Supply Chain Management as Private Sector Regulation: What does it Mean for Business Strategy and Public Policy?" Business Strategy and the Environment: n/an/a.

Foerstl, K., A. Azadegan, T. Leppelt and E. Hartmann (2015). "Drivers of Supplier Sustainability: Moving Beyond Compliance to Commitment." Journal of Supply Chain Management 51(1): 67-92. $\mathrm{Fu}, \mathrm{X} ., \mathrm{Q}$. Zhu and J. Sarkis (2012). "Evaluating green supplier development programs at a telecommunications systems provider." International Journal of Production Economics 140(1): 357367.

Giannakis, M. (2008). "Facilitating learning and knowledge transfer through supplier development." Supply Chain Management: An International Journal 13(1): 62-72.

Govindan, K., S. Seuring, Q. Zhu and S. G. Azevedo (2016). "Accelerating the transition towards sustainability dynamics into supply chain relationship management and governance structures." Journal of Cleaner Production 112: 1813-1823.

Hahn, C. K., C. A. Watts and K. Y. Kim (1990). "The supplier development program: a conceptual model." International Journal of Purchasing and Material Management 26(2): 2-7.

Hofmann, H., C. Busse, C. Bode and M. Henke (2014). "Sustainability-Related Supply Chain Risks: Conceptualization and Management." Business Strategy and the Environment 23(3): 160-172. Krause, D. R., T. V. Scannell and R. J. Calantone (2000). "A structural analysis of the effectiveness of buying firms' strategies to improve supplier performance." Decision Sciences 31(1): 33-55.

Lee, K.-H. and J.-W. Kim (2011). "Integrating Suppliers into Green Product Innovation Development: an Empirical Case Study in the Semiconductor Industry." Business Strategy and the Environment 20(8): 527-538.

Lewis, K. V., S. Cassells and H. Roxas (2015). "SMEs and the Potential for A Collaborative Path to Environmental Responsibility." Business Strategy and the Environment 24(8): 750-764.

Li, S., B. Ragu-Nathan, T. S. Ragu-Nathan and S. Subba Rao (2006). "The impact of supply chain management practices on competitive advantage and organizational performance." Omega 34(2): 107-124.

Liu, B., Q. Yu, B. Zhang, J. Bi, J. Ge, Z. Yuan and Y. Yu (2010). "Does the GreenWatch program work? Evidence from a developed area in China." Journal of Cleaner Production 18(5): 454-461.

Lu, R. X. A., P. K. C. Lee and T. C. E. Cheng (2012). "Socially responsible supplier development: Construct development and measurement validation." International Journal of Production Economics 140(1): 160-167.

Marshall, D., L. McCarthy, P. McGrath and F. Harrigan (2016). "What's Your Strategy for Supply Chain Disclosure?" Mit Sloan Management Review 57(2): 37-+. 
Meckenstock, J., A. P. Barbosa-Póvoa and A. Carvalho (2015). "The Wicked Character of Sustainable Supply Chain Management: Evidence from Sustainability Reports." Business Strategy and the Environment: n/a-n/a.

Mena, C., A. Humphries and T. Y. Choi (2013). "Toward a Theory of Multi-Tier Supply Chain Management." Journal of Supply Chain Management 49(2): 58-77.

Modi, S. B. and V. A. Mabert (2007). "Supplier development: Improving supplier performance through knowledge transfer." Journal of Operations Management 25(1): 42-64.

Morhardt, J. E. (2010). "Corporate Social Responsibility and Sustainability Reporting on the Internet." Business Strategy and the Environment 19(7): 436-452.

Niesten, E., A. Jolink, A. B. Lopes de Sousa Jabbour, M. Chappin and R. Lozano (2017). "Sustainable collaboration: The impact of governance and institutions on sustainable performance." Journal of Cleaner Production 155, Part 2: 1-6.

Oelze, N., S. U. Hoejmose, A. Habisch and A. Millington (2016). "Sustainable Development in Supply Chain Management: The Role of Organizational Learning for Policy Implementation." Business Strategy and the Environment 25(4): 241-260.

Pagell, M. and Z. Wu (2009). "BUILDING A MORE COMPLETE THEORY OF SUSTAINABLE SUPPLY CHAIN MANAGEMENT USING CASE STUDIES OF 10 EXEMPLARS." Journal of Supply Chain Management 45(2): 37-56.

Rodríguez, J. A., C. Giménez Thomsen, D. Arenas and M. Pagell (2016). "NGOs' Initiatives to Enhance Social Sustainability in the Supply Chain: Poverty Alleviation through Supplier Development Programs." Journal of Supply Chain Management 52(3): 83-108.

Rueda-Manzanares, A., J. A. Aragón-Correa and S. Sharma (2008). "The Influence of Stakeholders on the Environmental Strategy of Service Firms: The Moderating Effects of Complexity, Uncertainty and Munificence*." British Journal of Management 19(2): 185-203.

Sancha, C., A. Longoni and C. Gimenez (2015). "Sustainable supplier development practices: Drivers and enablers in a global context." Journal of Purchasing and Supply Management 21(2): 95-102.

Seuring, S. and M. Müller (2008). "Core issues in sustainable supply chain management - A Delphi study." Business Strategy and the Environment 17(8): 455-466.

Smith, P. A. C. (2012). "The importance of organizational learning for organizational sustainability." The Learning Organization 19(1): 4-10.

Tachizawa, E. M. and C. Y. Wong (2014). "Towards a theory of multi-tier sustainable supply chains: a systematic literature review." Supply Chain Management: An International Journal 19(5/6): 643-663. Touboulic, A., D. Chicksand and H. Walker (2014). "Managing Imbalanced Supply Chain Relationships for Sustainability: A Power Perspective." Decision Sciences 45(4): 577-619.

Vachon, S. and R. D. Klassen (2008). "Environmental management and manufacturing performance: The role of collaboration in the supply chain." International Journal of Production Economics 111(2): 299-315.

Vermeulen, W. J. V. (2015). "Self-Governance for Sustainable Global Supply Chains: Can it Deliver the Impacts Needed?" Business Strategy and the Environment 24(2): 73-85.

Voss, C., M. Johnson and J. Godsell (2016). Case Research. Research Methods for Operations

Management. C. Karlsson. New York, Routledge: 165-197.

Wagner, S. M. (2011). "Supplier development and the relationship life-cycle." International Journal of Production Economics 129(2): 277-283.

Wagner, S. M. and D. R. Krause (2009). "Supplier development: communication approaches, activities and goals." International Journal of Production Research 47(12): 3161-3177.

Wei, Y. and X. Liu (2006). "Productivity spillovers from R\&D, exports and FDI in China's manufacturing sector." Journal of International Business Studies 37(4): 544-557.

Wu, J. (2015). "Differentiated Customer Pressures and Environmental Policies in China." Business

Strategy and the Environment 24(3): 175-189.

Yawar, S. A. and S. Seuring (2015). "Management of Social Issues in Supply Chains: A Literature Review Exploring Social Issues, Actions and Performance Outcomes." Journal of Business Ethics: 1-23. 
Yin, R. (2002). Applications of Case Study Research Second Edition (Applied Social Research Methods Series Volume 34), Sage Publications, Inc.

Yin, R. (2009). Case Study Research. Design and Methods, 4th edition Sage Publications, Inc.

Zhu, Q., J. Sarkis and K.-h. Lai (2013). "Institutional-based antecedents and performance outcomes of internal and external green supply chain management practices." Journal of Purchasing and Supply Management 19(2): 106-117.

Zimmer, K., M. Froehling and F. Schultmann (2016). "Sustainable supplier management - a review of models supporting sustainable supplier selection, monitoring and development." International Journal of Production Research 54(5): 1412-1442. 
Table 1 Supplier development strategies and their sustainability context

\begin{tabular}{|c|c|c|}
\hline Strategies & $\begin{array}{l}\text { Definition \& typical } \\
\text { activities }\end{array}$ & Examples of sustainability context \\
\hline \multirow{2}{*}{$\begin{array}{l}\text { Competitive } \\
\text { pressure }\end{array}$} & \multirow{2}{*}{$\begin{array}{l}\text { Suppliers with better } \\
\text { performance get higher } \\
\text { volumes of business }\end{array}$} & $\begin{array}{l}\text { Take environmental or social performance } \\
\text { into consideration; }\end{array}$ \\
\hline & & $\begin{array}{l}\text { This performance can be part of core } \\
\text { competitiveness when related to quality and } \\
\text { stability. }^{3}\end{array}$ \\
\hline \multirow{3}{*}{ Incentives } & \multirow{3}{*}{$\begin{array}{l}\text { Profit-sharing, long-term } \\
\text { commitment, recognition } \\
\text { \& reward, etc. }\end{array}$} & $\begin{array}{l}\text { Give recognition and reward when suppliers } \\
\text { have high performance on sustainability }\end{array}$ \\
\hline & & $\begin{array}{l}\text { Co-design green products with suppliers as a } \\
\text { win-win solution (Lee and Kim 2011); }\end{array}$ \\
\hline & & $\begin{array}{l}\text { Promote recycling practices to reduce supplier } \\
\text { costs. }\end{array}$ \\
\hline \multirow{2}{*}{$\begin{array}{l}\text { Evaluation \& } \\
\text { Assessment }\end{array}$} & \multirow{2}{*}{$\begin{array}{l}\text { Monitoring, reporting and } \\
\text { verification, so that both } \\
\text { parties are aware of the } \\
\text { performance }\end{array}$} & $\begin{array}{l}\text { Implement environmental and social } \\
\text { metrics/indicators on a regular basis. Sharing } \\
\text { information among partners. (Vachon and } \\
\text { Klassen 2008). }\end{array}$ \\
\hline & & $\begin{array}{l}\text { Create contractual requirement and code of } \\
\text { conduct for sustainability purposes to rule out } \\
\text { suppliers with poor performance. }\end{array}$ \\
\hline \multirow{3}{*}{$\begin{array}{l}\text { Management } \\
\text { involvement }\end{array}$} & \multirow{3}{*}{$\begin{array}{l}\text { Make capital, human, } \\
\text { organizational, or } \\
\text { equipment investments }\end{array}$} & $\begin{array}{l}\text { Building suppliers' top management support } \\
\text { for the improvement of supplier performance } \\
\text { on sustainability; }\end{array}$ \\
\hline & & $\begin{array}{l}\text { Invest in on-site pollution control facilities for } \\
\text { suppliers; }\end{array}$ \\
\hline & & $\begin{array}{l}\text { Invest in robotic facilities to replace human } \\
\text { operators and eliminate risks of occupational } \\
\text { hazards. }\end{array}$ \\
\hline \multirow{2}{*}{$\begin{array}{l}\text { Knowledge } \\
\text { transfer }\end{array}$} & \multirow{2}{*}{$\begin{array}{l}\text { Direct interaction between } \\
\text { knowledge giver and } \\
\text { recipient }\end{array}$} & $\begin{array}{l}\text { Training programs that provide sustainability- } \\
\text { related knowledge at individual or } \\
\text { organizational level (Lewis et al. 2015); }\end{array}$ \\
\hline & & $\begin{array}{l}\text { Organizational knowledge transfer activities } \\
\text { (Modi and Mabert 2007) might not be } \\
\text { sufficient if the buying firm itself does not } \\
\text { have enough knowledge on sustainability. }\end{array}$ \\
\hline
\end{tabular}

\footnotetext{
${ }^{3}$ For example, more industrial worker accidents (that disrupt production) or environmental violations (that could lead to local authorities shut downs) will probably influence the quality \& stability of supplying products to the BF.

${ }^{4}$ For example, Walmart recognise their good-performance suppliers as "sustainability leaders" see: http://corporate.walmart.com/global-responsibility/environment-sustainability/sustainability-index-leadersshop
} 
Table 2 Information of interviewed organisations

\begin{tabular}{|c|c|c|c|c|c|c|}
\hline $\begin{array}{l}\text { Organization } \\
\text { type }\end{array}$ & $\begin{array}{l}\text { Industry sector and } \\
\text { \# of org. in each industry }\end{array}$ & & Overall \# & $\begin{array}{l}\# \text { of } \\
\text { interview } \\
\text {-ees }\end{array}$ & $\begin{array}{l}\text { Regions of } \\
\text { operation }\end{array}$ & $\begin{array}{l}\text { Size of organisation } \\
\text { by \# of employees (suppliers) or } \\
\text { annual revenue ( } \$ \text { ) for } 2016(\mathrm{BFs})\end{array}$ \\
\hline Suppliers & $\begin{array}{l}\text { Chemicals: } \\
\text { Electronics: } \\
\text { Household appliance: } \\
\text { Metal hardware: } \\
\text { Plastic hardware: } \\
\text { Textile \& apparel: } \\
\text { Toys: }\end{array}$ & $\begin{array}{l}2 \\
10 \\
6 \\
4 \\
2 \\
9 \\
8\end{array}$ & 41 & 54 & China & 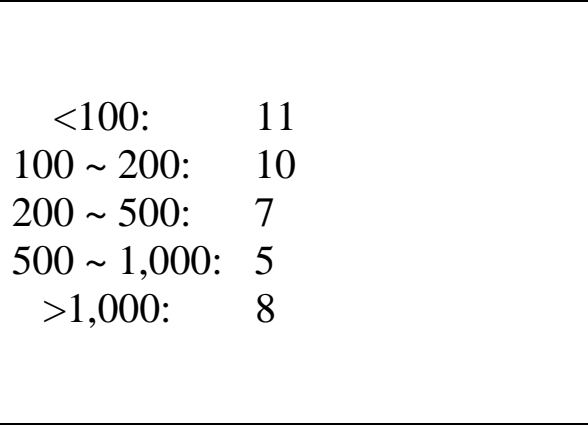 \\
\hline Buying firms & $\begin{array}{l}\text { Chemicals: } \\
\text { Electronics: } \\
\text { Household appliance: } \\
\text { Retailer \& Grocery: } \\
\text { Textile \& apparel: }\end{array}$ & $\begin{array}{l}1 \\
2 \\
2 \\
2 \\
2\end{array}$ & 9 & 13 & $\begin{array}{l}\text { US, Europe } \\
\text { and Asia }\end{array}$ & $\begin{array}{l}<20 \text { billion: } \quad 2 \\
20 \sim 100 \text { billion: } 5 \\
>100 \text { billion: } \quad 2\end{array}$ \\
\hline Contributors & $\begin{array}{l}\text { Researchers and external } \\
\text { experts in sustainability }(\mathrm{R}) \text { : } \\
\text { CSR or environmental } \\
\text { consulting \& training agencies } \\
\text { (C): } \\
\text { Industrial associations (A): } \\
\text { NGO for environmental } \\
\text { sustainability(N): }\end{array}$ & 3 & 13 & 18 & $\begin{array}{l}\text { US, Europe } \\
\text { and Asia }\end{array}$ & N/A \\
\hline
\end{tabular}


Table 3 SDS practices: key actions for different stages

\begin{tabular}{|c|c|c|c|}
\hline $\begin{array}{l}\text { Stages of SDS } \\
\text { practices }\end{array}$ & Definition \& typical activities & Buying firm (BF) actions & Supplier actions \\
\hline Designing & $\begin{array}{l}\text { Determine the scope of the program (time, } \\
\text { region, sustainability issues to be addressed) } \\
\text { and the theory of change (KPIs and how to } \\
\text { achieve them) }\end{array}$ & $\begin{array}{l}\text { Stakeholder concerns; } \\
\text { Goals and gap analysis; } \\
\text { Available resources (budget, } \\
\text { manpower, knowledge input, etc.) }\end{array}$ & $\begin{array}{l}\text { Benchmarking to understand the } \\
\text { sustainability-related performance } \\
\text { of their facilities and that of peers }\end{array}$ \\
\hline $\begin{array}{l}\text { Recruiting \& } \\
\text { engagement }\end{array}$ & $\begin{array}{l}\text { Determine the participating suppliers, and } \\
\text { establish supplier cohorts; } \\
\text { Prepare necessary expertise and resources for } \\
\text { the practices }\end{array}$ & $\begin{array}{l}\text { Engage with top management of } \\
\text { suppliers to facilitate recruiting; } \\
\text { Pre-competitive approach: joint- } \\
\text { engagement with competitors }\end{array}$ & $\begin{array}{l}\text { Communication: why am I } \\
\text { enrolled/not enrolled? } \\
\text { Demand analysis } \\
\text { Confirm managers and team } \\
\text { members as key participators; }\end{array}$ \\
\hline $\begin{array}{l}\text { Implementing } \\
\& \text { Monitoring }\end{array}$ & $\begin{array}{l}\text { Deliver knowledge or resource in order to } \\
\text { improve supplier performance; } \\
\text { Regular communication and summary to } \\
\text { ensure the practices are in good shape }\end{array}$ & $\begin{array}{l}\text { Managing program participation and } \\
\text { efforts. }\end{array}$ & $\begin{array}{l}\text { Utilize development opportunities } \\
\text { to cope with buyer requirement; } \\
\text { Peer/competitors communication } \\
\text { if any. }\end{array}$ \\
\hline $\begin{array}{l}\text { Conclusion } \\
\text { and reflections }\end{array}$ & $\begin{array}{l}\text { Complete program cycle and decide strategies } \\
\text { for future practices (if any); } \\
\text { Enlist new suppliers or replace current } \\
\text { suppliers into SDS practices when necessary }\end{array}$ & \multicolumn{2}{|c|}{$\begin{array}{l}\text { Review the cost, efforts and effectiveness of practices; } \\
\text { Scale up the positive impacts of SDS if any }\end{array}$} \\
\hline
\end{tabular}


Table 4 Roles, descriptions and strategies of SDS contributors

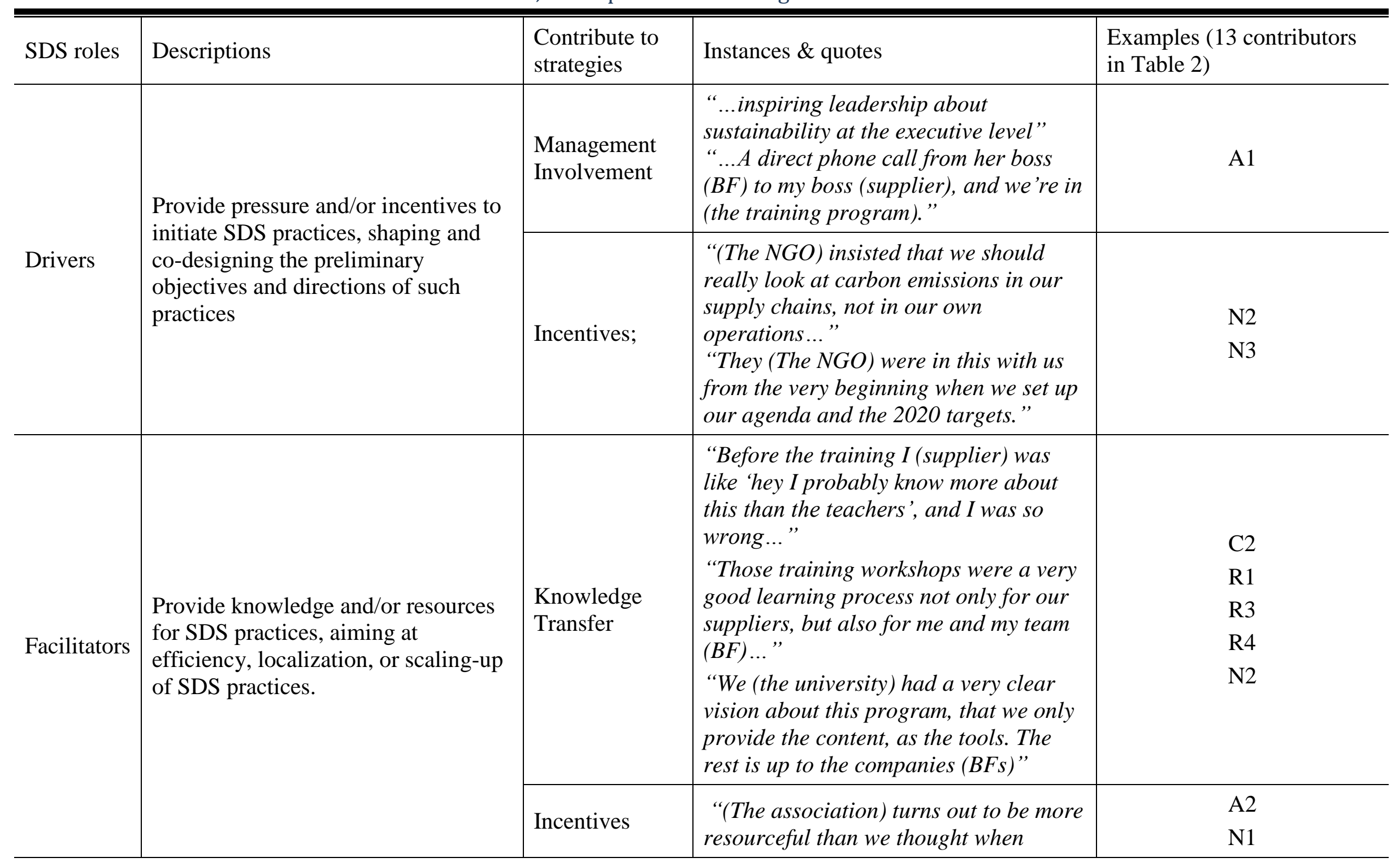




\begin{tabular}{|c|c|c|c|c|}
\hline & & & $\begin{array}{l}\text { reaching out to the upper stream of } \\
\text { apparel industries." } \\
\text { "We had other customers (BFs) } \\
\text { conducting audits of our safety } \\
\text { protocols. It is very relieving to see that } \\
\text { their requirements of us (supplier) are } \\
\text { being aligned among the customers. ", }\end{array}$ & \\
\hline \multirow[t]{2}{*}{ Inspectors } & \multirow{2}{*}{$\begin{array}{l}\text { Provide a neutral and scientific } \\
\text { ground, to advise and plan for SDS } \\
\text { goals and benchmarks, to validate the } \\
\text { performance of suppliers. }\end{array}$} & $\begin{array}{l}\text { Evaluation \& } \\
\text { Assessment }\end{array}$ & $\begin{array}{l}\text { "We (the consultants) presented } \\
\text { practical evidence that both the } \\
\text { production and environmental } \\
\text { performance of suppliers can be } \\
\text { improved. And we are on the list of (the } \\
\text { NGO's) third-party certification." } \\
\text { "It is extremely helpful for us (BF) to } \\
\text { see in the (supplier data) system, that } \\
\text { progress has been made every year, and } \\
\text { some suppliers are really improving } \\
\text { their water efficiency." }\end{array}$ & $\begin{array}{l}\text { C1 } \\
\text { R2 } \\
\text { N3 }\end{array}$ \\
\hline & & $\begin{array}{l}\text { Competitive } \\
\text { Pressure }\end{array}$ & $\begin{array}{l}\text { "If they (suppliers) scored only } 1 \text { or } 2 \\
\text { out of 5, they are kind of on our } \\
\text { blacklist, and we encourage our } \\
\text { members (BFs) not do procure from the } \\
\text { blacklist at all." } \\
\text { "We (supplier) take it very seriously } \\
\text { when they (reporting initiative) come } \\
\text { on-site to check our facility and data, } \\
\text { because we know they are working with } \\
\text { the customer closely." }\end{array}$ & $\begin{array}{l}\text { A3 } \\
\text { N4 }\end{array}$ \\
\hline
\end{tabular}


Table 5 Facilitators, Inspectors and their contribution to efforts and performance of SDS practices

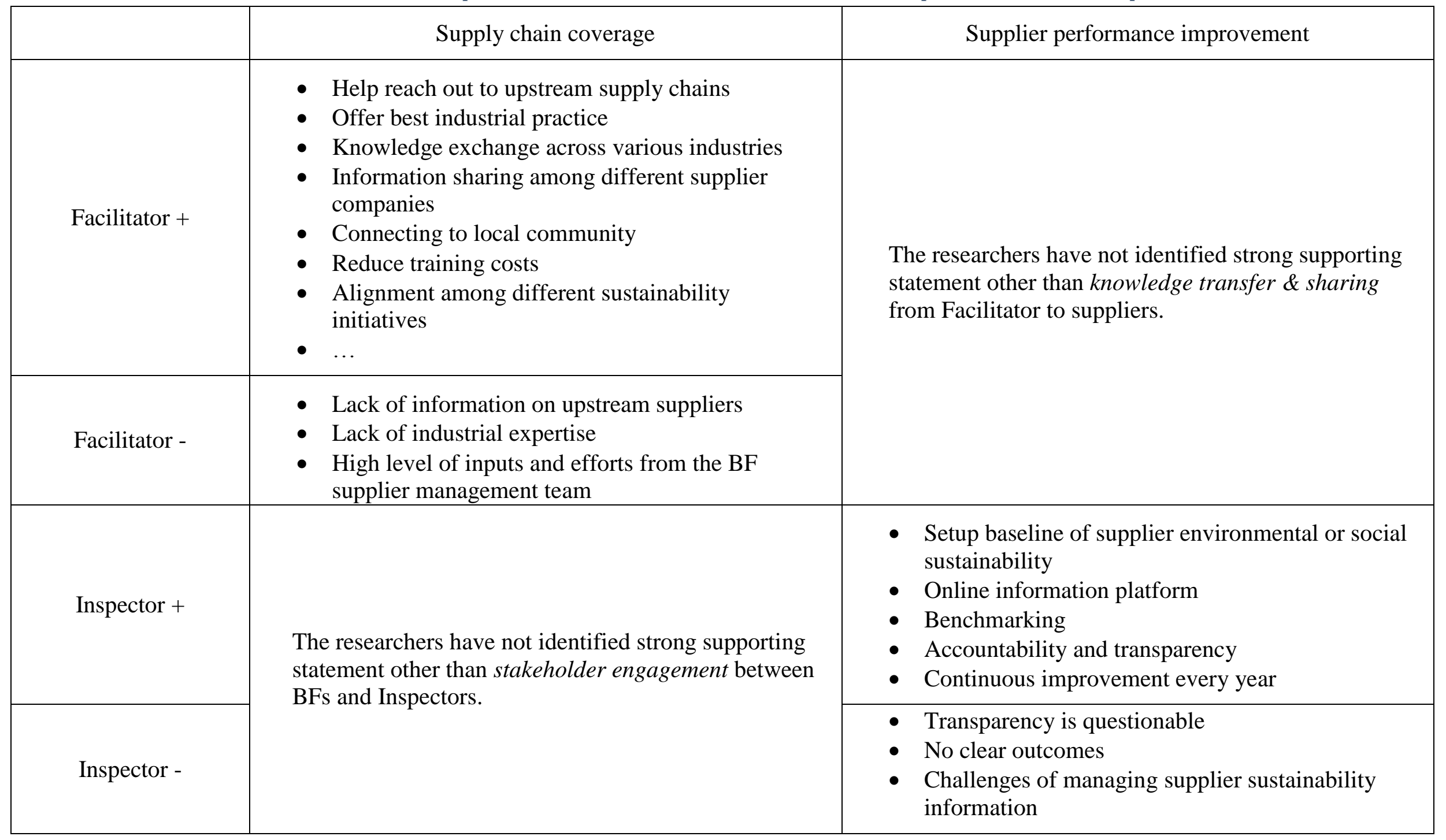


Appendix 1: Interview questions

\section{To suppliers}

Could you briefly describe your experience of participating in this (or your most recent) supplier development program?

Could you share with us why you and your company joined/are enrolled in this program?

Do you think you and your company is doing well in this program? How so?

Could you describe how you and your colleagues worked/are working with the customer company during this program?

Who else are you or your colleagues working with in order to complete the program with best results?

How would you describe you experience working with them (i.e., the contributors)?

What do you get from this program/those programs you participated in, that you think are most helpful to you and/or your team?

\section{To BFs}

Could you briefly describe your experience of managing/co-organising this (or your most recent) supplier development program?

Why in the first place does your team/leadership think that you would do this?

How do you recruit your suppliers and decide which ones should be enrolled?

How do you monitor the supplier development program during, for example, the past six months?

How does your company evaluate the program? Why are you (or not) looking at this/that aspect (e.g., refer to a statement in their report)?

Who else are you or your colleagues working with in order to complete the program with best results?

How would you describe your experience working with them (i.e., the contributors)?

Do you know about any other organisations that might help you achieve this/create this (i.e. the impact or outputs we just discussed)?

\section{To the contributors}

Could you briefly describe the role and mission of your organisation in this program?

At which point were your team involved/invited to the program? 
How would you describe you experience working with the supplier factories?

Who approached whom? Did they (BFs) come to you or it is the other way around?

How long has your organisation been doing this? What were you doing before, or do you have other plans for future initiatives?

A very frank and honest question: do you think there are other organisations or companies that can do what you do for similar programs? Why?

Most of the questions above are open-ended, while some unlisted questions were also used to quickly follow-up on the responses of interviewees towards specific questions, with the purpose of further understanding roles, strategies and/or stages of SDS practices. 